Article

\title{
In Ovo Delivery of CpG DNA Reduces Avian Infectious Laryngotracheitis Virus Induced Mortality and Morbidity
}

\section{Simrika Thapa ${ }^{1}$, Mohamed Sarjoon Abdul Cader ${ }^{1}$, Kalamathy Murugananthan ${ }^{1, \dagger}$, Eva Nagy ${ }^{2}$, Shayan Sharif ${ }^{2}$, Markus Czub ${ }^{1}$ and Mohamed Faizal Abdul-Careem ${ }^{1, *}$}

1 Faculty of Veterinary Medicine, University of Calgary, Health Research Innovation Center 2C64, 3330 Hospital Drive NW, Calgary, AB T2N 4N1, Canada; E-Mails: sthapa@ucalgary.ca (S.T.); sarjoonhafeez@gmail.com (M.S.A.C.); kalamathy6@gmail.com (K.M.); mmczub@ucalgary.ca (M.C.)

2 Department of Pathobiology, University of Guelph, Guelph, ON N1G 2W1, Canada; E-Mails: enagy@ovc.uoguelph.ca (E.N.); shayan@uoguelph.ca (S.S.)

$\dagger$ Current address: Faculty of Medicine, University of Jaffna, Jaffna 40000, Sri Lanka.

* Author to whom correspondence should be addressed; E-Mail: faizal.abdulcareem@ucalgary.ca; Tel.: +1-403-220-4462; Fax: +1-403-210-9740.

Academic Editor: Curt Hagedorn

Received: 20 December 2014 / Accepted: 26 March 2015 / Published: 8 April 2015

\begin{abstract}
Endosomal toll-like receptor-21 and -9 sense CpG DNA activating production of pro-inflammatory mediators with antimicrobial effects. Here, we investigated the induction of antiviral response of in ovo delivered $\mathrm{CpG}$ DNA against infectious laryngotracheitis virus (ILTV) infection. We found that in ovo delivered CpG DNA significantly reduces ILTV infection pre-hatch correlating with the expression of IL-1 $\beta$ and increase of macrophages in lungs. As assessed in vitro, CpG DNA stimulated avian macrophages could be a potential source of IL- $1 \beta$ and other pro-inflammatory mediators. Since we also found that in ovo CpG DNA delivery maintains increased macrophages in the lungs post-hatch, we infected the chickens on the day of hatch with ILTV. We found that in ovo delivered $\mathrm{CpG}$ DNA significantly reduces mortality and morbidity resulting from ILTV infection encountered post-hatch. Thus, CpG DNA can be a candidate innate immune stimulant worthy of further investigation for the control of ILTV infection in chickens.
\end{abstract}


Keywords: In ovo; toll-like receptor 21; CpG-motif containing synthetic DNA; infectious laryngotracheitis virus; lung; chicken

\section{Introduction}

Infectious laryngotracheitis virus (ILTV) is an enveloped virus with a double stranded DNA genome and belongs to the family Herpesviridae and subfamily alphaherpersvirinae [1,2]. The ILTV causes infectious laryngotracheitis (ILT) in chickens, pheasants and peafowls worldwide [3,4], transmitted through nasal and ocular routes and results in mild to severe respiratory manifestations. The severe form of ILTV infection leads to dyspnea and bloody respiratory mucus discharge leading to mortality rate up to $70 \%$ [5]. The mild form of the ILTV infection is characterized by depression, low egg production and loss of body weights. Induction of innate immune responses characterized by the mRNA expression of pro-inflammatory cytokines and chemokines has been shown following ILTV infection in embryonic lung epithelial cells in vitro [6]. Protection against ILTV infection in chickens appears to be dependent on cell -mediated rather than antibody-mediated immune responses [7,8]. In addition to biosecurity measures, live-attenuated vaccines are commonly used to prevent ILT, however, increase in virulence of the vaccine strains during bird-to-bird passage is common $[9,10]$ as has been recombination involving vaccine strains $[11,12]$. The limitations in current vaccine-mediated control necessitate investigations into novel control measures such as stimulation of innate immune responses in chickens.

Toll-like receptors (TLR) are a category of innate pattern recognition receptors that are responsible for recognizing pathogens via pathogen associated molecular patterns (PAMPs) at mucosal surfaces. Consequently, elicits innate immune responses linking adaptive arm of the immune system [13]. The mammalian immune system consists of TLR-1 to TLR-13 [14]. TLRs are generally conserved in vertebrates [15-17] except TLR-15 and TLR-21, which is unique for avian species [18,19]. In addition, the corresponding genes of mammalian TLR-8 and TLR-9 are absent in avian species [20-23], however TLR-21 is the functional counterpart of mammalian TLR-9 [19]. Similar to TLR-3, in chickens, TLR-21 is expressed in the endosomal compartment intracellularly [24] and responsible for sensing unmethylated CpG DNA [25].

CpG DNA motifs of microbial origin are known to be unmethylated and present in bacterial genome and genomes of DNA viruses at much higher frequencies than in eukaryotes [25]. Synthetic CpG DNA molecules are similar to CpG DNA originated from microbes. Depending on the structures as well as the immune responses generated, synthetic CpG DNA has been divided into three major classes, A, B and C [26]. Class A CpG DNA contains phosphodiester backbone with poly CpG DNA motifs at the center and the stimulation of cells by which leads to production of type 1 interferons (IFNs) [27,28]. Class B CpG DNA has a phosphorothioate backbone throughout and it is capable of stimulation of B cells and monocytes [28,29]. Class C CpG DNA molecules possess the properties of both class A and B CpG DNA molecules in terms of the structure and the function [30].

In mammals, it has been shown that CpG DNA could elicit protective responses in mice against bacterial infections, such as Leishmania major, Chlamydia trachomatis and Helicobacter pylori [31-33], viral infections, such as lymphocytic choriomeningitis virus (LCMV), hepatitis B virus (HBV), and 
poxvirus [34-36], and tumor conditions such as pulmonary metastases and B-cell lymphoma [37,38]. Additional to the antimicrobial and anti-tumor applications, $\mathrm{CpG}$ DNA is considered a potential vaccine adjuvant for human vaccines. Based on successful mice model data, human clinical studies are being conducted to investigate the efficacy of CpG DNA as an adjuvant against allergy, cancer and asthma [39-41], as well as hepatitis B infection [42,43].

In chickens, it has been shown that the CpG DNA is protective against bacterial infections, such as Escherichia coli [44,45], Salmonella Typhimurium [46] and S. Enteritidis [47], and viruses, such as avian influenza virus (AIV), in vivo [48] and in vitro [49]. In addition, protection in chickens against systemic E. coli and S. Typhimurium after hatch has been shown when CpG DNA has been delivered in ovo $[45,46]$. However, the roles CpG DNA play in the antiviral responses against avian viruses are scarce.

Furthermore, the mechanisms that lead to CpG DNA mediated antimicrobial effects in chickens have not been adequately investigated. The CpG DNA induced protection against $E$. coli and S. Enteritidis appears to be associated with increased functions of heterophils, including degranulation [44,50]. Recently, it has been shown that the activation of TLR-21 using CpG DNA in chicken macrophage cell line could enhance the expression of mRNA of pro-inflammatory cytokines such as IL-1 $\beta$ correlating with antiviral responses against AIV in vitro [49] and that indicates that macrophages could be another type of innate cell involved in the host responses induced by $\mathrm{CpG}$ DNA. It has also been recorded that the CpG DNA induced antiviral effects against IBV is associated with mRNA expression of cytokines, such as IFN- $\gamma$, IL-8 and MIP-1 $\beta$, in pre-hatch embryos $[51,52]$.

With a view of the lack of information on the $\mathrm{CpG}$ DNA-induced antiviral property in chickens, we hypothesized that TLR-21 ligand $\mathrm{CpG}$ DNA, when delivered in ovo, may induce antiviral responses and protection against morbidity and mortality caused by ILTV infection. We also hypothesized that the protection induced by in ovo CpG DNA delivery against ILTV infection is associated with expansion of macrophage populations pre- and post-hatch, as well as the production of pro-inflammatory mediators. The objectives of the study were to determine whether in ovo delivered CpG DNA mediate antiviral responses against ILTV infection encountered pre- and post-hatch and the protection against ILTV infection is associated with macrophage and pro-inflammatory responses in lungs of chickens.

\section{Results}

\subsection{In Ovo Delivery of CpG DNA Reduces Pre-Hatch ILTV Replication in Lung of Embryos} Correlating with Expansion of Macrophage Populations and Increased mRNA Expression of IL-1 $\beta$ in Lungs

As CpG DNA was reported to be able to induce antiviral responses in vivo and in vitro against AIV [48,49], we hypothesized that CpG DNA may be able to elicit antiviral responses against ILTV in vivo. For this experiment, we delivered $50 \mu \mathrm{g}$ of CpG DNA per egg in ovo at ED18 with controls receiving non-CpG DNA so that treatment is available in amniotic cavity and challenged the embryos after $24 \mathrm{~h}$ through the same route. We found a significant decrease in ILTV mRNA expression in the lung of CpG DNA-treated embryos when compared to the controls ( $p=0.0249$, Figure 1a). 
Then, we quantified the mRNA expression of the downstream molecules in the lung coinciding with the time of ILTV challenge in ovo, i.e., 24 h post CpG DNA treatment. We found that following CpG DNA treatment IL-1 $\beta$ mRNA expressions in lungs were significantly increased when compared to non-CpG DNA controls $(p=0.0105$, Figure $1 b)$ and not the mRNA expression of iNOS ( $p \geq 0.05$, Figure 1c).

The immunohistochemistry staining of the lung tissues sampled $24 \mathrm{~h}$ following the in ovo delivery of CpG DNA, non-CpG DNA or PBS at ED18 embryos showed a significant increase in the macrophage numbers in CpG DNA treated group (Figure 1d) when compared to the non-CpG DNA treated group ( $p=0.0448)$ and the PBS treated group $(p=0.0370)$. There was no significant difference between non-CpG DNA treated and PBS treated groups in terms of macrophage numbers in lung tissue pre-hatch $(p>0.05)$.

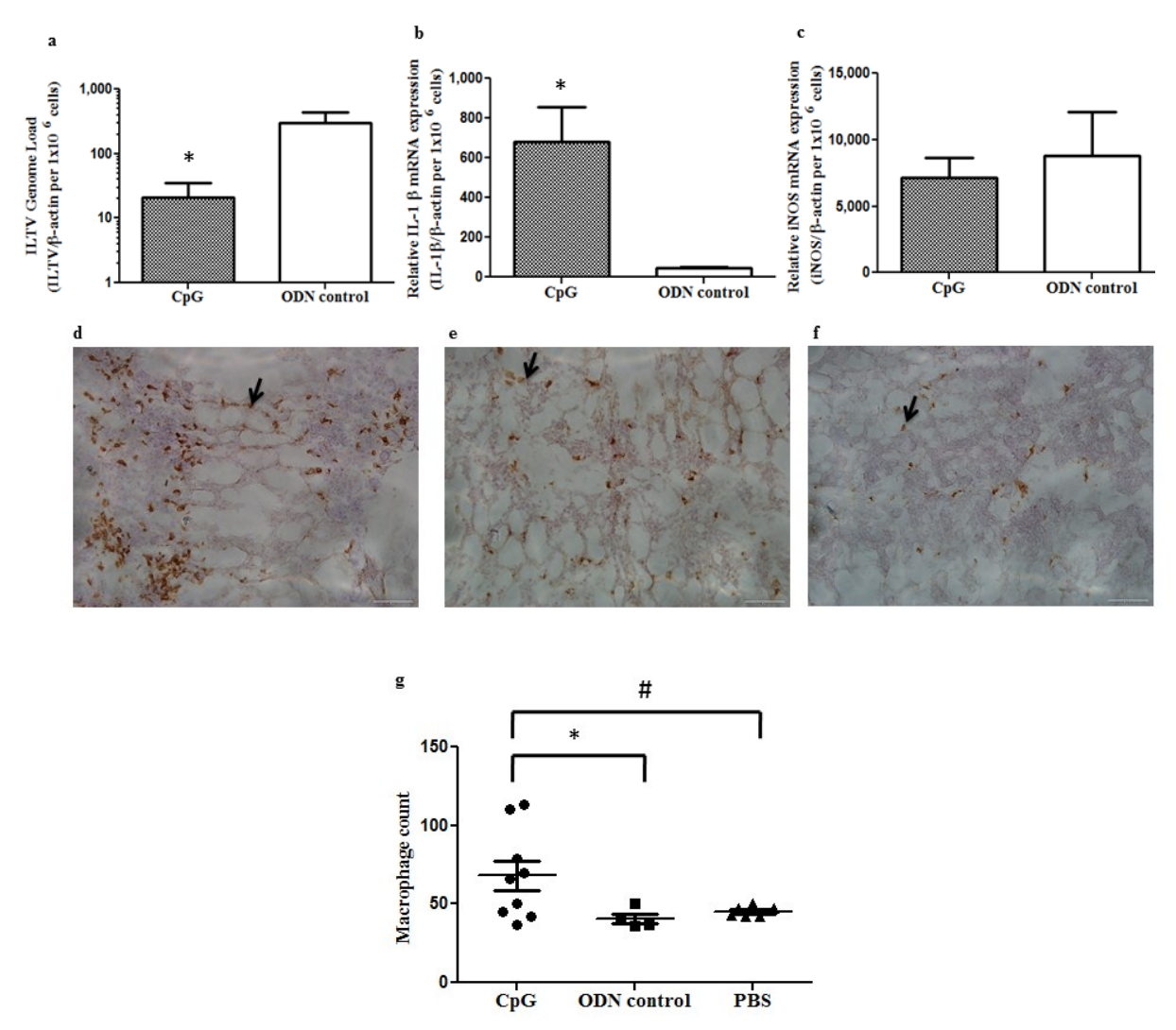

Figure 1. In ovo delivery of $\mathrm{CpG}$ DNA reduces ILTV replication pre-hatch in lung of chicken embryos correlating with expansion of macrophage populations and increased mRNA expression of IL-1 $\beta$ in lungs 24 h post treatment: (a) pre-hatch mRNA expression of ILTV protein kinase (PK) gene in lungs following in ovo CpG DNA or PBS delivery; (b-c) mRNA expression of IL-1 $\beta$ (b) and iNOS (c) that will be activated downstream of CpG DNA- TLR21 interaction following in ovo CpG DNA or PBS delivery; (d) macrophages in lungs pre-hatch following in ovo delivery of CpG DNA, non-CpG DNA and PBS $24 \mathrm{~h}$ post treatment (ED19). Arrows show KUL01+ macrophages $*=$ significant at $p \leq 0.05$ when $\mathrm{CpG}$ DNA treated and non-CpG DNA treated groups were compared and \#= significant at $p \leq 0.05$ when CpG DNA treated and PBS treated groups were compared. 


\subsection{Stimulation of Macrophages in Vitro with CpG DNA up Regulates $m R N A$ Expression of}

\section{Pro-Inflammatory Mediators and Increases NO Production}

Since we observed in ovo delivery of CpG DNA increased macrophage numbers and IL-1 $\beta$ mRNA expression in lungs pre-hatch, in order to clarify a potential source of IL-1 $\beta$ mRNA, we conducted an in vitro experiment stimulating an avian macrophage cell line (MQ-NCSU) with CpG DNA and non-CpG DNA. Following the stimulation, we quantified the mRNA expression of iNOS, which leads to NO production in addition to IL-1 $\beta$. The NO production was found to be significantly high in MQ-NCSU cells following CpG DNA treatment when compared to that received non-CpG DNA at 1 $(p=0.0456), 3(p=0.0033), 6(p=0.0112)$ and $12 \mathrm{~h}(p=0.0195)$ post-treatment (Figure 2a). There was a significant increase in the mRNA expression of iNOS in cells treated with CpG DNA when compared to the controls at $6(p=0.0435)$ and $12 \mathrm{~h}(p=0.0376)$ post-treatment (Figure $2 \mathrm{~b})$. The mRNA expressions of IL-1 $\beta$ at $3(p=0.0100), 6(p=0.0161)$ and $12 \mathrm{~h}(p=0.0290)$ post-treatment were also significantly higher than that in controls (Figure $2 c)$.

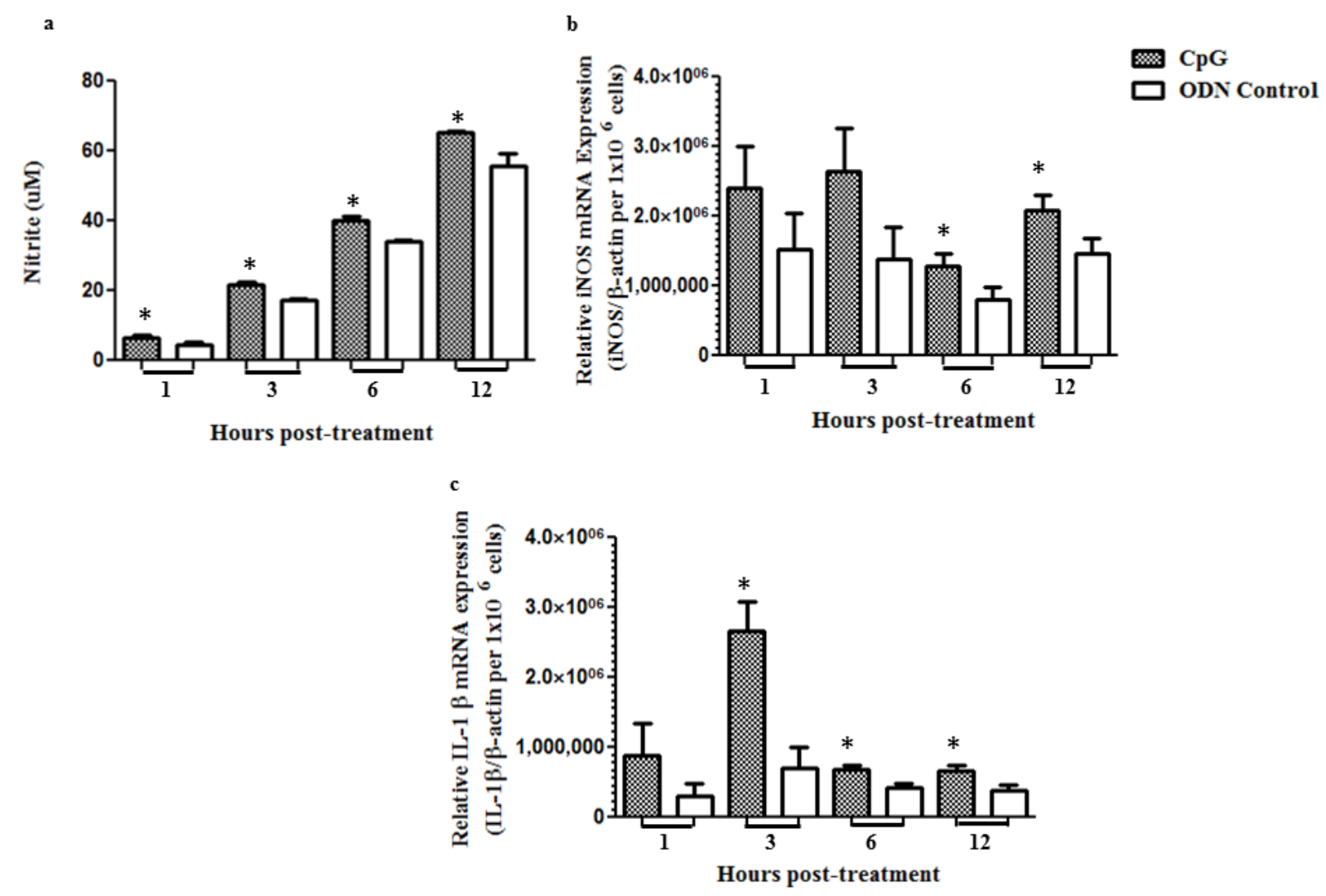

Figure 2. Stimulation of chicken macrophages cell line in vitro with $\mathrm{CpG}$ DNA up regulates mRNA expression of pro-inflammatory mediators and increases NO production. Avian macrophage cell line, MQ-NCSU were seeded in 6 well plates $\left(2 \times 10^{6}\right.$ cells/well $)$, cultured overnight, growth medium was removed and washed with $1 \times$ HBSS. CpG DNA stimulation was done at $10 \mu \mathrm{M}$ in phenol red free complete RPMI 1640 without antibiotics. Control for the CpG DNA treatment was non-CpG DNA treatment done at the same concentration. The plates were incubated for $1,3,6$ and $12 \mathrm{~h}$ at $40{ }^{\circ} \mathrm{C}$ under $5 \% \mathrm{CO}_{2}$ before collection of culture supernatants for NO (a) assay and cells in Trizol for RNA extraction and real-time RT-PCR for the quantification of iNOS (b) and IL-1 $\beta$ (c) mRNA. 
Each treatment was done in triplicate and the experiment was done twice under same conditions. ${ }^{*}=$ significant at $p \leq 0.05$ when student's $t$-test was used.

Since we found the CpG DNA mediated increase in the expression of mRNA of iNOS and IL-1 $\beta$ as well as NO production by the avian macrophage cell line, MQ-NCSU, we confirmed these findings with primary chicken blood monocyte derived macrophages. We hypothesized that blood monocyte derived macrophages increase in the expression of mRNA of iNOS and IL-1 $\beta$ along with NO production following the CpG DNA treatment when compared to non-CpG DNA treatment. We observed a significant increase in NO production at $12 \mathrm{~h}$ post-treatment $(p<0.0001$, Figure 3a). Similarly, there was a significant increase in the expressions of iNOS $(p<0.0001$, Figure $3 b)$ and IL-1 $\beta$ ( $p=0.0003$, Figure $3 \mathrm{c}$ ) after 12 h post-treatment ( $p<0.05$, Figure $3 \mathrm{~d})$.

$$
\text { a }
$$

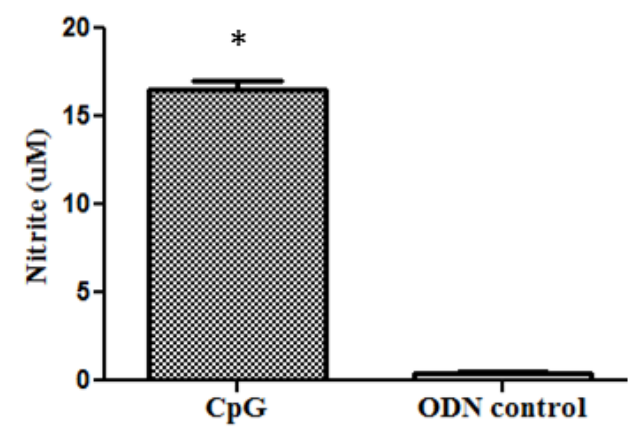

c

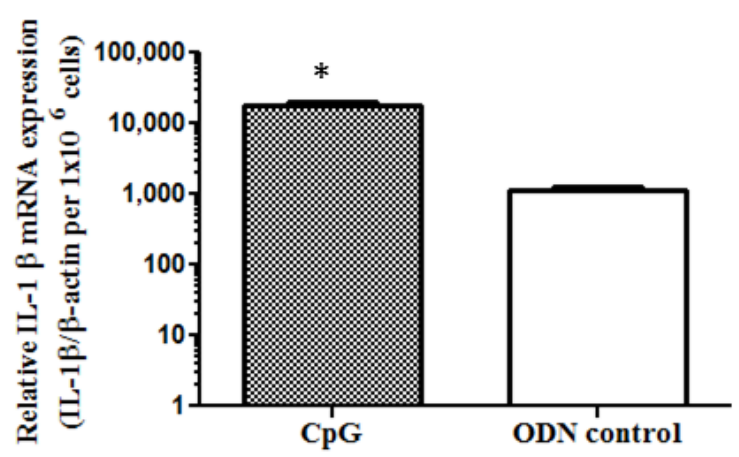

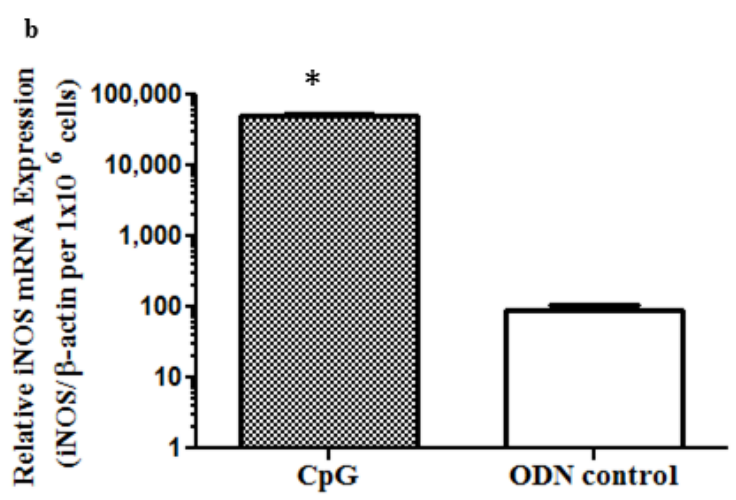

d

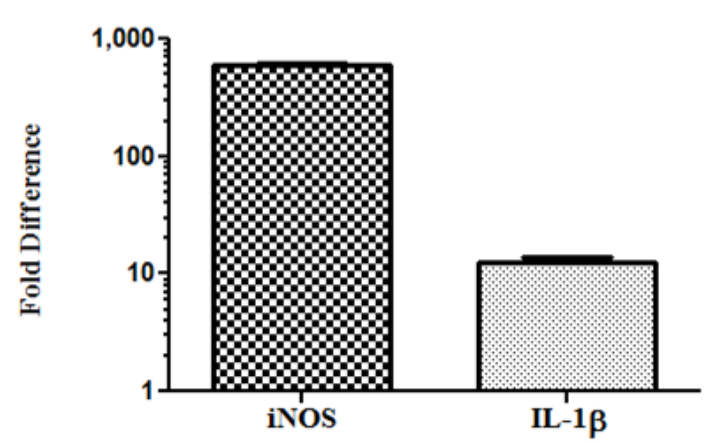

Figure 3. Stimulation of primary chicken macrophages in vitro with $\mathrm{CpG}$ DNA up regulates mRNA expression of pro-inflammatory mediators and increases NO production. Blood derived macrophages $\left(1.5 \times 10^{6}\right.$ cells per well $)$ were stimulated with $10 \mu \mathrm{M}$ of $\mathrm{CpG}$ DNA in phenol red free complete RPMI 1640 without antibiotics and same concentration non-CpG DNA treatment was used as control for the determination of NO (a) and the mRNA expression of iNOS (b) and IL-1 $\beta$ (c) at $12 \mathrm{~h}$ post-stimulation; (d) represents the fold difference in iNOS and IL-1 $\beta$ expressions by CpG DNA treated macrophage cells when compared to non-CpG DNA treated group. Differences between groups were analyzed using student's $t$-test. $*=$ significant at $p \leq 0.05$ when student's $t$-test was used. 


\subsection{In Ovo Delivery of CpG DNA Expands Macrophage Numbers in Lungs Post-Hatch}

Since in ovo delivered CpG DNA in ED18 eggs resulted macrophage population expansion in embryonic lungs after $24 \mathrm{~h}$ post-treatment, we hypothesized that the increased macrophage numbers following in ovo CpG DNA delivery may be maintained in lungs post-hatch. For the investigation of expansion of lung macrophage numbers post-hatch following in ovo CpG DNA delivery, we quantified the macrophages in lungs post-hatch using flow cytometry technique. We found that in ovo CpG DNA treatment significantly increased the macrophage numbers post-hatch when compared to that in non-CpG DNA treated controls chickens (Figure 4, $p=0.0041$ ).
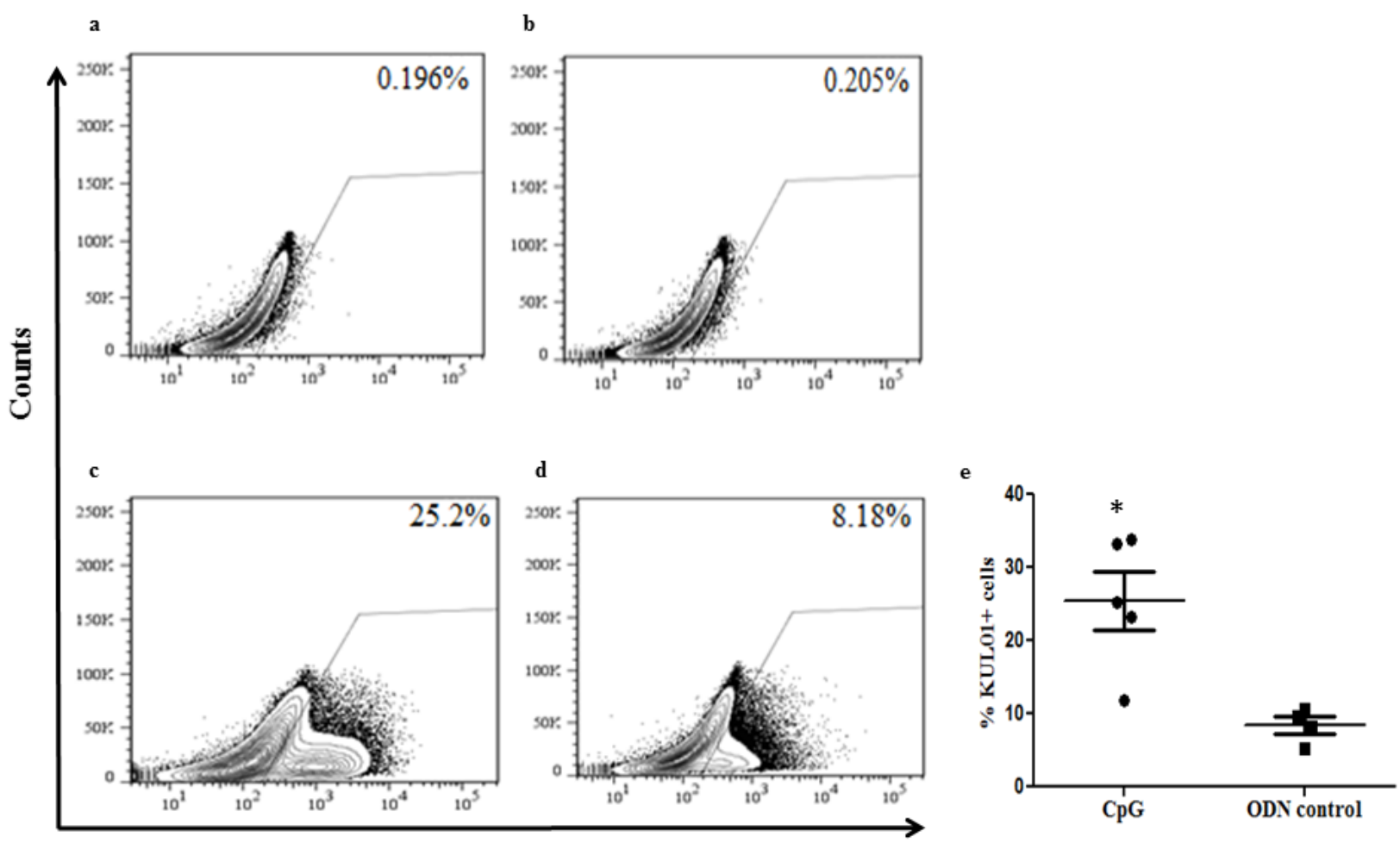

PE-KUL01+ cells

Figure 4. In ovo delivery of CpG DNA expands macrophage numbers in lungs post-hatch. (a-d) indicate the representative fluorescence-activated cell sorting diagrams showing unstained control, iso type control, percentage of KUL01+ macrophages in lungs post-hatch originated from in ovo $\mathrm{CpG}$ DNA and non-CpG DNA treated groups respectively. (e) illustrates the percentage of KUL01+ macrophages in lungs post-hatch originated from in ovo CpG DNA or non-CpG DNA delivered groups. * indicates significant differences between groups at $p<0.05$.

\subsection{In Ovo Delivery of CpG DNA Induces Protection against ILTV Caused Morbidity and Mortality} Reducing Viral Replication in the Respiratory Tract of Chickens

Since we observed that in ovo delivered CpG DNA was capable of increasing lung macrophages post-hatch, we then hypothesized that the chickens that received in ovo CpG DNA leading to increased macrophages post-hatch may be able elicit protective response against ILTV infection encountered post-hatch. For this part of the study, we in ovo delivered either CpG DNA or PBS, allowed the eggs to 
hatch and then infected the hatched chickens intratracheally with ILTV on the day of hatch. We found that in ovo delivered CpG DNA (1) decreases clinical signs associated with post-hatch ILTV infection $(p<0.0001$, Figure 5a); (2) protects chickens from loss of bodyweights associated with post-hatch ILTV infection ( $p=0.021$, Figure 5b); (3) decreases mortality associated with post-hatch ILTV infection ( $p<0.0001$, Figure 5c); and (4) decreases ILTV replication as assessed by mRNA expression of ILTV PK gene ( $p=0.0276$, Figure 5d) and absolute ILTV genome load in tracheal swabs at seven days post-infection ( $p=0.0114$, Figure 5e).

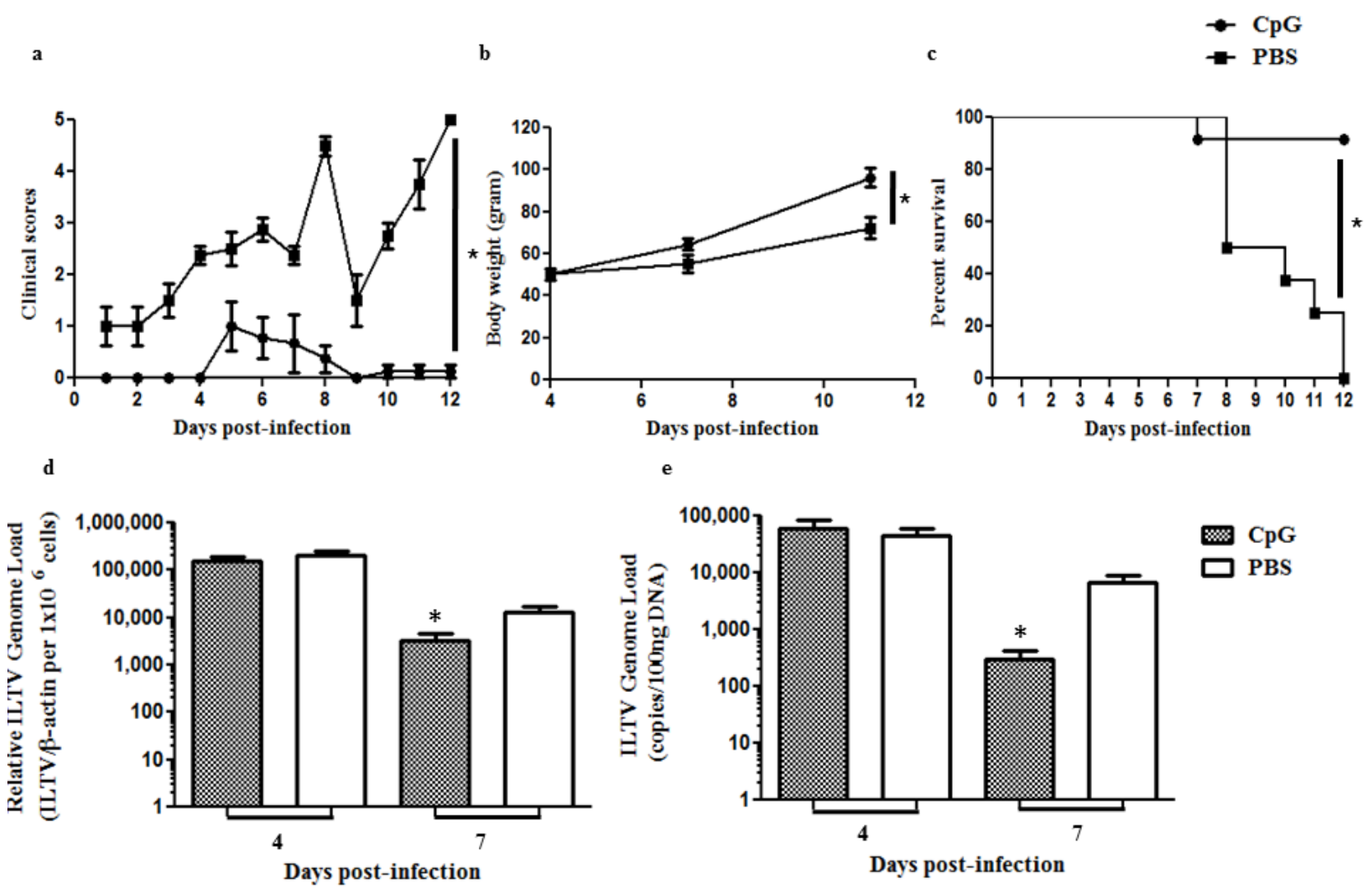

Figure 5. In ovo delivery of CpG DNA induces protection against ILTV caused morbidity and mortality reducing viral replication in the respiratory tract of chickens. SPF eggs were injected with CpG DNA or PBS in ovo, allowed to hatch and hatched chickens were infected with $5 \times 10^{4}$ PFU of ILTV intratracheally. The infected chickens were observed for 12 days post-infection for development of clinical signs and determination of the end points as has been described in the materials and methods section. The chickens were also weighed (4, 7 and 11 days post-infection) and tracheal swabs (4 and 7 days post-infection) were collected for quantification of ILTV PK gene mRNA expression and genome load using real-time RT-PCR technique. (a) clinical scores; (b) bodyweights; (c) survival proportions, (d) ILTV PK gene mRNA expression as assessed in tracheal swabs using cDNA as template and (e) ILTV genome load in tracheal swabs using DNA as template. * indicates the significant differences between groups at $p<0.05$. 


\subsection{In Ovo Delivery of CpG DNA Does Not Affect the Hatchability of Eggs}

We recorded hatchability rates of $86 \%$ and $75 \%$ following in ovo delivery of CpG DNA and PBS, respectively.

\section{Discussion}

Our current investigations led to three major findings. Firstly, CpG DNA decreases ILTV replication in lungs pre-hatch correlating with expansion of macrophage populations and increase in mRNA expression of IL-1 $\beta$ in lungs. Secondly, we found that avian macrophages could be stimulated with CpG DNA in vitro to produce NO and increase in mRNA expression of iNOS and IL-1 $\beta$ genes. Finally, CpG DNA elicits protective responses against mortality and morbidity resulting from ILTV infection in chickens encountered post-hatch and this protection was associated with a reduction in ILTV replication in the lungs at a late stage of infection in the in ovo CpG DNA delivered chickens as well as a significant expansion of macrophage populations in lungs post-hatch.

In ovo route has been investigated for the delivery of CpG DNA against bacterial infections, such as E. coli and S. Typhimurium, encountered post-hatch $[45,46]$ and found to be protective against morbidity and mortality caused by these bacterial agents. It has also been shown that in ovo delivered CpG DNA is efficacious as an antiviral agent against pre-hatch IBV infection [51,52]. The data we gathered in the current study show that in ovo delivery of $\mathrm{CpG}$ DNA could protect chickens from morbidity and mortality of ILTV infection encountered post-hatch implying the potential applicability of our findings for ILTV control.

It has been shown that host responses against ILTV infection may represent initial innate responses characterized by expression of pro-inflammatory cytokine and chemokine genes [53]. It has also been observed that protective host responses against ILTV infection are associated with cell-mediated rather than antibody-mediated immune responses $[7,8]$. Infiltration of cells such as polymorphonuclear cells, macrophages and lymphocytes in trachea following ILTV infection has been recorded [54]. In fact, it is not clear what lung cellular components of the innate and adaptive arms are involved in the protection against ILTV infection in chickens. In the current study we observed that the in ovo delivery of CpG DNA related protection against morbidity and mortality induced by ILTV infection is associated with the expansion of macrophage populations in lungs pre- and post-hatch. It has been shown that CpG DNA act as a ligand for TLR-21 in chickens [19,55]. The activation of TLR-21 leads to the production of pro-inflammatory mediators [56]. In agreement with this observation, in the current study, we observed that CpG DNA treatment in vivo increases the mRNA expression of IL-1 $\beta$ in lungs pre-hatch. IL-1 $\beta$ is a known chemotactic factor for immune cells such as macrophages [57]. It is possible that the recruitment of macrophage populations in lungs pre- and post-hatch following in ovo CpG DNA delivery in our study could be due to the chemotactic function of IL-1 $\beta$. In a different context, it has been recorded that $\mathrm{CpG}$ DNA treatment in mouse models increase recruitment of macrophages [58,59] and these records confirm our finding of increased macrophage populations in lungs following in ovo CpG DNA delivery. Secondly, it is also possible that CpG DNA treatment increases survival of macrophages increasing the number of macrophages accumulate in a tissue over a period of time. Our view of increased survival of macrophages leading to increased number of 
macrophages overtime could be supported by the finding that $\mathrm{CpG}$ motifs present in Leishmania donovani is able to inhibit programmed cell death in macrophages [60].

There are three potential circumstances to clarify the observed difference in ILTV PK gene transcripts and genome load between CpG DNA treated and controls in the present study. Firstly, there would have been a possible phagocytic role of the recruited macrophage in clearing some of the ILTV infected cells since it has been shown previously that macrophages could involve in clearing influenza virus infected cells in mice through phagocytosis [61]. Secondly, it is possible that differential NO production in macrophages between CpG DNA treated and control groups contributed to the observed difference in viral replication. To support our second view, we conducted an in vitro experiment using a macrophage cell line and primary macrophages and found increased production of NO by macrophages following CpG DNA treatment when compared to controls. In agreement with this explanation it has been shown previously that NO is inhibitory against avian herpes viruses including ILTV [62-64]. Thirdly, it is possible that differential cytokine production in macrophages between CpG DNA treated and control groups contributed to the observed difference in viral replication. It has been shown that macrophages in chickens are a known source of pro-inflammatory cytokines such as IL-1 $\beta$ [65] and IL-1 $\beta$ is known to possess direct and indirect antiviral effects that have been recorded in other host-virus models $[57,66]$. We also found in our study that the mRNA of IL-1 $1 \beta$ gene was up-regulated in the lungs following in ovo delivery of $\mathrm{CpG}$ DNA. We recorded that macrophages could be a source of IL-1 $\beta$ mRNA following stimulation with CpG DNA. Altogether, macrophages appear to be involved in the reduction of pre- and post-hatch ILTV infection in the respiratory tract following in ovo CpG DNA delivery.

Although we observed a reduction in the ILTV replication in lungs at a late time point in chickens originated from CpG DNA treated embryos, at four days post-infection we did not observe a difference in ILTV replication between CpG DNA treated and control chickens. Similarly, we did not see a difference in bodyweights between the CpG DNA treated and control chickens at four days post-infection but a significant difference between these two groups were observed at late time points following ILTV infection. These observations suggest that protection mediated by in ovo delivery of CpG DNA is not entirely depend on early innate immune responses characterized by lung macrophage population expansion and increase of expression of pro-inflammatory mediators such as NO and IL-1 $\beta$. One potential mechanism may be the rapid development of adaptive immune responses in chickens that received in ovo CpG DNA when compared to the chickens that received PBS in ovo. In agreement with this view, it has been shown that CpG DNA could protect neonatal piglets from E.coli infection induced by enterotoxigenic strains correlating with development of adaptive immune responses, particularly mucosal antibody responses [67]. Further, CpG DNA has been shown to stimulate B cells leading to antibody production in mammals [68]. Secondly, it is possible that ILTV may be using macrophages for viral replication at the same rate of clearing ILTV infected cells using various mechanisms in the CpG DNA treated chickens at the early time points. In supporting our view, it has been shown that ILTV could utilize macrophages for it's replication [69],

In ovo delivery of antigens is extensively investigated as poultry disease control methods since it is vital, due to ubiquitous nature of pathogen distribution in poultry barn environments, to employ control methods pre-hatch. Induction of host responses pre-hatch empowers the birds' immune system at hatch and minimizes the window of susceptibility. In fact, non-pathogenic avian herpes viruses and 
attenuated virulent viruses have been routinely used as in ovo vaccines most notably for the control of Marek's disease in chickens [70]. These in ovo-administered MD vaccines have proven to be efficacious in preventing morbidity and mortality induced by the causative virus. In the present study we observed that in ovo delivery of CpG DNA could expand macrophage populations pre-hatch as well as post-hatch strengthening the innate arm of the immune system of the hatched chickens. We also showed that the CpG DNA induced host responses such a way was capable of reducing mortality and morbidity resulted from ILTV infection encountered post-hatch. The anti-ILTV activity of CpG DNA was also found to be associated with the up regulation of mRNA of IL-1 $\beta$ pre-hatch. Finally, we show that in ovo delivery of CpG DNA found to be safe in terms of hatchability of the incubated eggs. It is imperative to investigate whether this pre-hatch stimulation of innate immune responses with $\mathrm{CpG}$ DNA also leads to the quick and solid antigen specific adaptive immune response against ILTV.

\section{Materials and Methods}

\subsection{Animals}

All procedures requiring the use of eggs and embryos have been approved by the University of Calgary's Veterinary Sciences Animal Care Committee and Health Sciences Animal Care Committee. Specific Pathogen Free (SPF) eggs were purchased from Canadian Food Inspection Agency, Ottawa, Canada and incubated at the Veterinary Science Research Station (VSRS) or Health Research Innovation Center (HRIC), University of Calgary. The hatched chickens were maintained in high containment poultry isolators either at VSRS or Prion/virology animal facility at HRIC, University of Calgary.

\subsection{Cells, Virus and TLR-Ligand}

An avian macrophage cell line, MQ-NCSU, used in this study was provided by Dr. Shayan Sharif (University of Guelph, Canada). Chicken blood derived macrophages were isolated from blood as has been described previously [71]. ILTV (strain N-71851) was purchased from the American Type Culture Collection (ATCC, Manassas, VA, USA). CpG DNA 2007 and non-CpG DNA 2007 were purchased from Cedarlane (Burlington, ON, Canada).

\subsection{Cell Culture}

Avian macrophage, MQ-NCSU cells were cultured in LM HAHN medium which consisted of Leibovitz L-15 medium (39.5\%), McCoy's 5A medium (39.5\%), chicken serum (10\%), L-glutamine (1\%), sodium pyruvate $(1 \%), 100$ units of penicillin and $100 \mu \mathrm{g}$ of streptomycin per $\mathrm{mL}$, fungizone $(250 \mu \mathrm{g} / \mathrm{mL}), 2-\mathrm{mercaptoethanol}(1.0 \mathrm{mM})$ (Invitrogen, Burlington, ON, Canada), tryptose phosphate broth (1\%) (Sigma-Aldrich, St. Louis, MO, USA), and fetal bovine serum (8\%) (Cellgro, Manassas, VA, USA) [72]. The cells were maintained at $40{ }^{\circ} \mathrm{C}$ at $5 \%$ carbon dioxide $\left(\mathrm{CO}_{2}\right)$ in an incubator.

For the isolation of chicken peripheral blood monocyte derived macrophages jugular blood was collected in heparinized tubes and mixed with an equal volume of phosphate-buffered saline (PBS). The mixture was subjected to Ficoll gradient density centrifugation using Ficoll-Paque ${ }^{\mathrm{TM}}$ PLUS (GE Healthcare Bio-Sciences AB, Uppsala, Sweden) at $400 \times \mathrm{g}$ for $40 \mathrm{~min}$ at $20{ }^{\circ} \mathrm{C}$. The cells at the 
interface were collected, discarding the upper plasma layer in the tube. The cells were washed in PBS and pelleted by centrifuging at $400 \times \mathrm{g}$ for $5 \mathrm{~min}$ at $4{ }^{\circ} \mathrm{C}$. This washing step was repeated three times. Finally, the cells were resuspended in RPMI-1640 with 5\% chicken serum, 2\% Hepes (Gibco Life Technologies, Burlington, ON, Canada), 100 units of penicillin and $100 \mu \mathrm{g}$ of streptomycin per ml and $100 \mu \mathrm{M}$ of L-glutamine and plated in T175 $\left(175 \mathrm{~cm}^{2}\right)$ flasks and incubated at $40^{\circ} \mathrm{C}$ for $48 \mathrm{~h}$.

\subsection{Experimental Design}

\subsubsection{The Antiviral Effect of in Ovo Delivered CpG DNA against Pre-Hatch ILTV Infection and} Determination of Correlates of Antiviral Effect

In order to determine the antiviral effect of in ovo delivered CpG DNA, a group of ED18 eggs $(n=4-5)$ were injected with $50 \mu \mathrm{g}$ CpG DNA in $200 \mu \mathrm{L}$ PBS per egg and each eggs in control group $(n=4)$ were injected with $50 \mu \mathrm{g}$ non-CPG DNA in $200 \mu \mathrm{L}$ PBS to investigate the efficacy of in ovo delivered $\mathrm{CpG}$ motifs against pre-hatch ILTV infection. After $24 \mathrm{~h}$ of in ovo delivery, each egg was infected with $1 \times 10^{5}$ PFU of ILTV per egg in ovo. The embryos were euthanized to collect lungs for RNA extraction $24 \mathrm{~h}$ post-infection. The experiment was done in duplicate (total of $n=9$ in CpG DNA group and $n=8$ in non-CpG DNA group).

In order to determine the mRNA expression of innate mediators (IL-1 $\beta$ and iNOS) that will be activated following in ovo delivery of CpG DNA, $24 \mathrm{~h}$ following treatment, the lungs of embryos from both CpG DNA treated group $(n=3)$ and non-CpG DNA treated group $(n=4)$ were collected for RNA extraction.

In order to determine the expansion of innate cells that will be recruited in lungs following in ovo delivery of CpG DNA, the lungs of embryos from both CpG DNA treated group $(n=9)$, non-CpG DNA treated group $(n=4)$ and PBS treated group $(n=6)$ were collected $24 \mathrm{~h}$ following treatment in optimal cutting temperature (OCT) compound (Tissue-Tek ${ }^{\circledR}$, Sakura Finetek USA inc, Torrance, CA, USA) before snap freezing in dry ice. Cryosections were evaluated using immunohistochemistry technique for macrophage identification.

\subsubsection{Stimulation of Macrophages in Vitro with CpG DNA to Determine the Expression of} Pro-Inflammatory Mediators

MQ-NCSU cells were propagated and cells were seeded in 6 well plates $\left(2 \times 10^{6}\right.$ cells $/$ well $)$. After culturing the cells overnight, growth medium was removed and washed with $1 \times$ Hanks balanced salt solution (HBSS) (Invitrogen, Burlington, ON, Canada). CpG DNA stimulation was done at $10 \mu \mathrm{M}$ in phenol red free RPMI 1640 (Invitrogen, Burlington, ON, Canada) containing 10\% FBS, $2.0 \mathrm{mM}$ L-Glutamine, and no antibiotics. The plates were incubated for $1,3,6$ and $12 \mathrm{~h}$ at $40{ }^{\circ} \mathrm{C}$ under $5 \% \mathrm{CO}_{2}$ before collection of culture supernatants for NO assay and cells for RNA extraction. Each treatment was done in triplicate in two separate experiments and the results were pooled before being analyzed.

To confirm our major finding in vitro, we used chicken peripheral blood derived macrophages. After $24 \mathrm{~h}$ of culture of chicken peripheral blood derived mononuclear cells, the media was changed and after $48 \mathrm{~h}$, the adhered cells were trypsinized using TrypLE ${ }^{\mathrm{TM}}$ Express (Life Technologies, Burlington, ON, Canada) and counted using hemocytometer. A total of $1.5 \times 10^{6}$ cells per well were 
cultured in 6-well plates and incubated for $24 \mathrm{~h}$. Then the cells were treated with CpG (10 uM) prepared in phenol red free RPMI 1640 containing 10\% FBS, $2.0 \mathrm{mM}$ L-Glutamine, and no antibiotics and untreated wells with media alone were kept as control. After $12 \mathrm{~h}$ post-treatment, both supernatant and cells were collected from the wells using cell scrapper for RNA extraction. The experiment was done in triplicate.

\subsubsection{In Ovo Delivered CpG mediated Expansion of Macrophage Populations in Lungs Post-Hatch}

For the evaluation of expansion of lung macrophage cell populations following in ovo CpG DNA delivery, ED18 embryos were injected with $50 \mu \mathrm{g}$ CpG DNA in $200 \mu \mathrm{L}$ PBS $(n=5)$ or non-CpG DNA control in $200 \mu \mathrm{L}$ PBS $(n=4)$ per egg. The eggs from both groups were allowed to hatch and on the day of hatch the chickens were euthanized to collect lungs for characterization of macrophages using flow cytometry technique.

\subsubsection{In Ovo Delivery of CpG DNA Mediated Protection against ILTV Caused Morbidity and Mortality in Chickens}

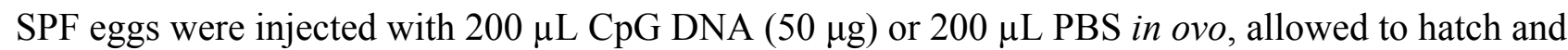
hatched chickens (CpG DNA, $n=9$ and PBS, $n=8$ ) were infected with $5 \times 10^{4}$ PFU of ILTV intratracheally. The infected chickens were observed daily for 12 days post-infection for development of clinical signs and determination of the end points. We considered that the chicken had reached the end point when the bird was assigned a cumulative score of 5 (ruffled feathers and huddling together $=1$, droopy wings $=1$, depression or head lowered with no movement $=1$, mild increase in the respiratory rate $=1$, increased respiratory rate with constant beak opening $=2$, very severe increased respiratory rate as marked by gasping $=3$ and bodyweight loss rather than gain $=1$ ). The chickens were also weighed (4, 7 and 11 days post-infection) and tracheal swabs (4 and 7 days post-infection) were collected for quantification of ILTV PK gene mRNA expression and genome load using real-time RT-PCR and PCR techniques respectively.

\subsubsection{Determination of Safety of in Ovo Delivery of CpG DNA}

We treated ED18 eggs in ovo with $50 \mu \mathrm{g}$ CpG DNA $(n=22)$ and allowed to hatch along with PBS $(n=68)$ treated eggs to evaluate the hatchability.

\subsection{Primers}

The ILTV mRNA expression in lung was quantified for investigating ILTV replication using primers specific for the PK gene of ILTV as has been described previously [73] using cDNA as a template. The primers used in the relative quantification of host genes using cDNA as template were published previously [73].

\subsection{DNA and RNA Extraction}

DNA and RNA extractions from cells and respiratory tissues were carried out using Trizol reagent (Invitrogen Canada Inc., Burlington, ON, Canada) as has been described previously for other tissues [74]. 


\subsection{Reverse Transcription}

RNA concentration was quantified using Nanodrop 1000 spectrophotometer at $260 \mathrm{~nm}$ wavelength (ThermoScientific, Wilmington, DE, USA). Reverse transcription of extracted RNA (2000 ng) was carried out using 10XRT random primers (High Capacity cDNA Reverse Transcription Kit, Invitrogen Life Technologies, Carlsbad, CA, USA) according to the manufacturer's instructions.

\subsection{Assay for NO Production}

Culture supernatants were assayed for NO production using a Griess reagent system (Promega, Madison, WI, USA) according to the manufacturer's recommendation. The concentration of NO was quantified against a standard curve. Absorbance of the resulting colorimetric product, NO in the supernatant made in the reaction with sulfanilamide and $N$-1-naftyletylendiamin dihydrochloride was read at $548 \mathrm{~nm}$.

\subsection{Flow Cytometry Technique}

Standard flow cytometry procedures were used in the experiments. Briefly, the collected lungs were chopped into small pieces and treated with $400 \mathrm{U} / \mathrm{mL}$ collagenase type I solution (Sigma-Aldrich, Oakville, ON, Canada) for $30 \mathrm{~min}$ at $37{ }^{\circ} \mathrm{C}$, and neutralized by HBSS. Then the cells were layered onto equal volume of Ficoll-Paque ${ }^{\mathrm{TM}}$ PLUS (GE Healthcare Bio-Sciences AB, Uppsala, Sweden) and centrifuged for $40 \mathrm{~min}$ at $400 \times \mathrm{g}$ at $20{ }^{\circ} \mathrm{C}$. The cloudy interphase layer was collected, pelleted, and washed with HBSS, and then the mononuclear cells were resuspended in complete medium. Then the cells were washed with $1 \%$ bovine serum albumin (BSA) fraction V (w/v; OmniPur, EMD, Darmstadt, Germany) made in PBS and centrifuged for 10 minutes at $1500 \times \mathrm{g}\left(4{ }^{\circ} \mathrm{C}\right)$ and then suspended in $100 \mu \mathrm{L}$ of 1:100 chicken serum (Invitrogen, Burlington, ON, Canada) (diluted in 1\% BSA) for Fc blocking. Following centrifugation, the pellets were resuspended with a final concentration of $0.02 \mathrm{ug} / \mu \mathrm{L}$ mouse anti-chicken macrophage-monocyte phycoerythrin (PE) (SouthernBiotech, Birmingham, AL, USA) monoclonal antibody in the dark and incubated for $30 \mathrm{~min}$ on ice. The respective isotype control and unstained control were also included in the experiment. Finally, cells were washed twice with $1 \%$ BSA. The samples were analyzed with a BD LSR II (BD Biosciences, Mississauga, ON, Canada).

\subsection{Immunohistochemistry Technique}

The immunohistochemistry technique was performed as has been described previously (Abdul-Careem et al., 2009). The lungs collected $24 \mathrm{~h}$ following in ovo delivery of CpG DNA, non-CpG DNA or PBS ( $n=4-9)$ in order to enumerate macrophages in the lungs. The expansion of macrophage numbers was assessed quantitatively in each section by counting KUL01 positive cells with clear outlines in five highly infiltrated fields at $40 \times$ magnification. 


\subsection{Real-Time PCR Assay}

All the DNA and cDNA preparations were analyzed using qPCR assays, alongside a dilution series of the plasmids used to generate the standard curve. All qPCR assays were conducted in a 96-well un-skirted, low profile PCR plate (VWR, Edmonton, AB, Canada) in a reaction volume of $20 \mu \mathrm{L}$. Fast SYBR $^{\circledR}$ Green Master Mix (Invitrogen, Burlington, ON, Canada) containing AmpliTaq ${ }^{\circledR}$ Fast DNA Polymerase was used for this assay. The DNA intercalating SYBR ${ }^{\circledR}$ Green dye was used for detection in a CFX96 Real-Time System C1000 Thermal Cycler (Bio-Rad Laboratories, Mississauga, ON, Canada). In addition, $5 \mathrm{nM}$ of each of the gene-specific primers and $9 \mu \mathrm{L}$ of a 1:10 dilution series of plasmid DNA, or $100 \mathrm{ng}$ of cDNA extracted from each lung sample and MQ-NCSU cells, 20ng of cDNA from tracheal swabs and 50ng of cDNA from primary macrophages used in the reaction. RNAse-free water was used as the negative control. The optimum thermal cycling parameters for mRNA of IL1- $\beta$ and iNOS, $\beta$ actin and ILTV PK gene included pre-incubation at $95{ }^{\circ} \mathrm{C}$ for $20 \mathrm{~s} ; 40$ cycles of amplification/extension at $95{ }^{\circ} \mathrm{C}$ for $3 \mathrm{~s}$, and $60{ }^{\circ} \mathrm{C}$ for $30 \mathrm{~s}$; melting curve analysis at $95{ }^{\circ} \mathrm{C}$ for $10 \mathrm{~s}$ (Segment 1 ), $65^{\circ} \mathrm{C}$ for $5 \mathrm{~s}$ (Segment 2) and $9{ }^{\circ} \mathrm{C}$ for $5 \mathrm{~s}$ (Segment 3). Fluorescent acquisition was done at $60{ }^{\circ} \mathrm{C}$ for $30 \mathrm{~s}$.

\subsection{Data Analyses}

In vitro $\mathrm{NO}$ concentrations and mRNA expressions were analyzed using student's $t$-test using GraphPad Prism 4 (GraphPad Prism Software, La Jolla, CA, USA, 2009) in order to identify differences between groups. In vivo data that compared ILTV genome load, ILTV PK gene mRNA expression and mRNA expression of pro-inflammatory molecules between CpG DNA treated and control chickens were also analyzed using student's $t$-test. Before being tested, each set of data was analyzed using the Grubbs' test (GraphPad software Inc., La Jolla, CA, USA, 2014) to identify outliers. Differences in survival between in ovo CpG DNA and control chickens were analyzed by chi-square $\left(\chi^{2}\right)$ test using GraphPad Prism 4 (GraphPad Prism Software, La Jolla, CA, USA, 2009). Group differences in bodyweights was analyzed by ANOVA and clinical scores by Krusal-Wallis test using the statistical package, MINITAB ${ }^{\circledR}$ release 14 (Minitab Inc., State College, PA, USA, 2004). Comparisons were considered significant at $p \leq 0.05$.

\section{Acknowledgments}

Simrika Thapa is a recipient of Dean's excellence award from the University of Calgary Faculty of Veterinary Medicine. This study was funded by the Canadian Poultry Research Council, Alberta Livestock and Meat Agency and Natural Sciences and Engineering Research Council of Canada through a NSERC RTI grant. We would like to acknowledge the staff, especially Brenda Roszell and Kenwyn White of the Veterinary Science Research Station at Spy Hill, University of Calgary and Sampson Law and Angelo Bianchi of the Prion/virology animal facility at Foothill campus, University of Calgary for experimental animal management. We would also like to thank Adam Chernick and Cristina Solis for blind scoring of immunohistochemistry images. We thank University of Calgary Veterinarian, Greg Muench for the support in performing animal procedures. 


\section{Author Contributions}

Simrika Thapa conducted the major part of the experiment and contributed to writing, Mohamed Sarjoon Abdul Cader and Kalamathy Murugananthan contributed for the laboratory analysis of the samples. Markus Czub, Mohamed Faizal Abdul-Careem, Shayan Sharif and Eva Nagy conceived the project and design the experiments with inputs from Simrika Thapa.

\section{Conflict of Interest}

The authors declare no conflict of interests.

\section{References}

1. McGeoch, D.J.; Dolan, A.; Ralph, A.C. Toward a comprehensive phylogeny for mammalian and avian herpesviruses. J. Virol. 2000, 74, 10401-10406.

2. McGeoch, D.J.; Rixon, F.J.; Davison, A.J. Topics in herpesvirus genomics and evolution. Virus Res. 2006, 117, 90-104.

3. Fahey, K.J.; Bagust, T.J.; York, J.J. Laryngotracheitis herpesvirus infection in the chicken: The role of humoral antibody in immunity to a graded challenge infection. Avian Pathol. 1983, 12, 505-514.

4. Crawshaw, G.J.; Boycott, B.R. Infectious laryngotracheitis in peafowl and pheasants. Avian Dis. 1982, 26, 397-401.

5. Bagust, T.J.; Jones, R.C.; Guy, J.S. Avian infectious laryngotracheitis. Rev. Sci. Technol. 2000, 19, 483-492.

6. Lee, Y.J.; Park, S.S.; Kim, S.Y.; Lee, J.Y.; Koo, H.K.; Yoon, H.I. A case of systemic polyarteritis nodosa involving bronchial artery. Sarcoidosis Vasc. Diffuse Lung Dis. 2010, 27, 164-168.

7. Fahey, K.J.; Bagust, T.J.; York, J.J. Laryngotracheitis Herpesvirus-Infection in the Chicken-The Role of Humoral Antibody in Immunity to a Graded Challenge Infection. Avian Pathol. 1983, 12, 505-514.

8. Honda, T.; Okamura, H.; Taneno, A.; Yamada, S.; Takahashi, E. The Role of Cell-Mediated-Immunity in Chickens Inoculated with the Cell-Associated Vaccine of Attenuated Infectious Laryngotracheitis Virus. J. Vet. Med. Sci. 1994, 56, 1051-1055.

9. Chang, P.C.; Lee, Y.L.; Shien, J.H.; Shieh, H.K. Rapid differentiation of vaccine strains and field isolates of infectious laryngotracheitis virus by restriction fragment length polymorphism of PCR products. J. Virol. Methods 1997, 66, 179-86.

10. Oldoni, I.; Rodriguez-Avila, A.; Riblet, S.; Garcia, M. Characterization of infectious laryngotracheitis virus (ILTV) isolates from commercial poultry by polymerase chain reaction and restriction fragment length polymorphism (PCR-RFLP). Avian Dis. 2008, 52, 59-63.

11. Lee, S.W.; Devlin, J.M.; Markham, J.F.; Noormohammadi, A.H.; Browning, G.F.; Ficorilli, N.P.; Hartley, C.A.; Markham, P.F. Phylogenetic and molecular epidemiological studies reveal evidence of multiple past recombination events between infectious laryngotracheitis viruses. PLOS ONE 2013, 8, e55121. 
12. Lee, S.W.; Markham, P.F.; Coppo, M.J.; Legione, A.R.; Markham, J.F.; Noormohammadi, A.H.; Browning, G.F.; Ficorilli, N.; Hartley, C.A.; Devlin, J.M. Attenuated vaccines can recombine to form virulent field viruses. Science 2012, 337, 188.

13. Akira, S.; Takeda, K.; Kaisho, T. Toll-like receptors: Critical proteins linking innate and acquired immunity. Nat. Immunol. 2001, 2, 675-680.

14. O’Neill, L.A.; Golenbock, D.; Bowie, A.G. The history of Toll-like receptors-Redefining innate immunity. Nat. Rev. Immunol. 2013, 13, 453-460.

15. Lillehoj, H.S.; Li, G. Nitric oxide production by macrophages stimulated with coccidia sporozoites, lipopolysaccharide, or interferon- $\gamma$, and its dynamic changes in SC and TK strains of chickens infected with Eimeria tenella. Avian Dis. 2004, 48, 244-253.

16. Lynn, D.J.; Lloyd, A.T.; O'Farrelly, C. In silico identification of components of the Toll-like receptor (TLR) signaling pathway in clustered chicken expressed sequence tags (ESTs). Vet. Immunol. Immunopathol. 2003, 93, 177-184.

17. Philbin, V.J.; Iqbal, M.; Boyd, Y.; Goodchild, M.J.; Beal, R.K.; Bumstead, N.; Young, J.; Smith, A.L. Identification and characterization of a functional, alternatively spliced Toll-like receptor 7 (TLR7) and genomic disruption of TLR8 in chickens. Immunology 2005, 114, 507-521.

18. Boyd, A.C.; Peroval, M.Y.; Hammond, J.A.; Prickett, M.D.; Young, J.R.; Smith, A.L. TLR15 is unique to avian and reptilian lineages and recognizes a yeast-derived agonist. J. Immunol. 2012, 189, 4930-4938.

19. Brownlie, R.; Zhu, J.; Allan, B.; Mutwiri, G.K.; Babiuk, L.A.; Potter, A.; Griebel, P. Chicken TLR21 acts as a functional homologue to mammalian TLR9 in the recognition of CpG oligodeoxynucleotides. Mol. Immunol. 2009, 46, 3163-3170.

20. Cormican, P.; Lloyd, A.T.; Downing, T.; Connell, S.J.; Bradley, D.; O'Farrelly, C. The avian Toll-Like receptor pathway-Subtle differences amidst general conformity. Dev. Comp. Immunol. 2009, 33, 967-973.

21. Roach, J.C.; Glusman, G.; Rowen, L.; Kaur, A.; Purcell, M.K.; Smith, K.D.; Hood, L.E.; Aderem, A. The evolution of vertebrate Toll-like receptors. Proc. Natl. Acad. Sci. USA 2005, 102, 9577-9582.

22. Schwarz, H.; Schneider, K.; Ohnemus, A.; Lavric, M.; Kothlow, S.; Bauer, S.; Kaspers, B.; Staeheli, P. Chicken toll-like receptor 3 recognizes its cognate ligand when ectopically expressed in human cells. J. Interferon Cytokine Res. 2007, 27, 97-101.

23. Temperley, N.D.; Berlin, S.; Paton, I.R.; Griffin, D.K.; Burt, D.W. Evolution of the chicken Toll-like receptor gene family: A story of gene gain and gene loss. BMC Genomics 2008, 9, e62.

24. Nishiya, T.; DeFranco, A.L. Ligand-regulated chimeric receptor approach reveals distinctive subcellular localization and signaling properties of the Toll-like receptors. J. Biol. Chem. 2004, 279, 19008-19017.

25. Hemmi, H.; Takeuchi, O.; Kawai, T.; Kaisho, T.; Sato, S.; Sanjo, H.; Matsumoto, M.; Hoshino, K.; Wagner, H.; Takeda, K.; et al. A Toll-like receptor recognizes bacterial DNA. Nature 2000, 408, 740-745.

26. Krieg, A.M. Therapeutic potential of Toll-like receptor 9 activation. Nat. Rev. Drug. Discov. 2006, 5, 471-484. 
27. Verthelyi, D.; Ishii, K.J.; Gursel, M.; Takeshita, F.; Klinman, D.M. Human peripheral blood cells differentially recognize and respond to two distinct CPG motifs. J. Immunol. 2001, 166, 2372-2377.

28. Hartmann, G.; Weeratna, R.D.; Ballas, Z.K.; Payette, P.; Blackwell, S.; Suparto, I.; Rasmussen, W.L.; Waldschmidt, M.; Sajuthi, D.; Purcell, R.H.; et al. Delineation of a $\mathrm{CpG}$ phosphorothioate oligodeoxynucleotide for activating primate immune responses in vitro and in vivo. J. Immunol. 2000, 164, 1617-1624.

29. Gursel, M.; Verthelyi, D.; Gursel, I.; Ishii, K.J.; Klinman, D.M. Differential and competitive activation of human immune cells by distinct classes of $\mathrm{CpG}$ oligodeoxynucleotide. J. Leukoc. Biol. 2002, 71, 813-820.

30. Marshall, J.D.; Fearon, K.; Abbate, C.; Subramanian, S.; Yee, P.; Gregorio, J.; Coffman, R.L.; van Nest, G. Identification of a novel CpG DNA class and motif that optimally stimulate B cell and plasmacytoid dendritic cell functions. J. Leukoc. Biol. 2003, 73, 781-792.

31. Zimmermann, S.; Egeter, O.; Hausmann, S.; Lipford, G.B.; Rocken, M.; Wagner, H.; Heeg, K. $\mathrm{CpG}$ oligodeoxynucleotides trigger protective and curative Th1 responses in lethal murine leishmaniasis. J. Immunol. 1998, 160, 3627-3630.

32. Cheng, C.; Bettahi, I.; Cruz-Fisher, M.I.; Pal, S.; Jain, P.; Jia, Z.; Holmgren, J.; Harandi, A.M.; de la Maza, L.M. Induction of protective immunity by vaccination against Chlamydia trachomatis using the major outer membrane protein adjuvanted with $\mathrm{CpG}$ oligodeoxynucleotide coupled to the nontoxic B subunit of cholera toxin. Vaccine 2009, 27, 6239-6246.

33. Nystrom-Asklin, J.; Adamsson, J.; Harandi, A.M. The adjuvant effect of CpG oligodeoxynucleotide linked to the non-toxic B subunit of cholera toxin for induction of immunity against H. pylori in mice. Scand. J. Immunol. 2008, 67, 431-440.

34. Oxenius, A.; Martinic, M.M.; Hengartner, H.; Klenerman, P. CpG-containing oligonucleotides are efficient adjuvants for induction of protective antiviral immune responses with $\mathrm{T}$-cell peptide vaccines. J. Virol. 1999, 73, 4120-4126.

35. Davis, H.L.; Weeratna, R.; Waldschmidt, T.J.; Tygrett, L.; Schorr, J.; Krieg, A.M. CpG DNA is a potent enhancer of specific immunity in mice immunized with recombinant hepatitis B surface antigen. J. Immunol. 1998, 160, 870-876.

36. Belyakov, I.M.; Isakov, D.; Zhu, Q.; Dzutsev, A.; Klinman, D.; Berzofsky, J.A. Enhancement of $\mathrm{CD} 8+\mathrm{T}$ cell immunity in the lung by $\mathrm{CpG}$ oligodeoxynucleotides increases protective efficacy of a modified vaccinia Ankara vaccine against lethal poxvirus infection even in a CD4-deficient host. J. Immunol. 2006, 177, 6336-6343.

37. Whitmore, M.M.; DeVeer, M.J.; Edling, A.; Oates, R.K.; Simons, B.; Lindner, D.; Williams, B.R. Synergistic activation of innate immunity by double-stranded RNA and CpG DNA promotes enhanced antitumor activity. Cancer Res. 2004, 64, 5850-5860.

38. Weiner, G.J.; Liu, H.M.; Wooldridge, J.E.; Dahle, C.E.; Krieg, A.M. Immunostimulatory oligodeoxynucleotides containing the $\mathrm{CpG}$ motif are effective as immune adjuvants in tumor antigen immunization. Proc. Natl. Acad. Sci. USA 1997, 94, 10833-10837. 
39. Tulic, M.K.; Fiset, P.O.; Christodoulopoulos, P.; Vaillancourt, P.; Desrosiers, M.; Lavigne, F.; Eiden, J.; Hamid, Q. Amb a 1-immunostimulatory oligodeoxynucleotide conjugate immunotherapy decreases the nasal inflammatory response. J. Allergy Clin. Immunol. 2004, 113, 235-241.

40. Krieg, A.M. Development of TLR9 agonists for cancer therapy. J. Clin. Invest. 2007, 117, 1184-1194.

41. Carpentier, A.; Laigle-Donadey, F.; Zohar, S.; Capelle, L.; Behin, A.; Tibi, A.; Martin-Duverneuil, N.; Sanson, M.; Lacomblez, L.; Taillibert, S.; et al. Phase 1 trial of a $\mathrm{CpG}$ oligodeoxynucleotide for patients with recurrent glioblastoma. Neuro. Oncol. 2006, 8, 60-66.

42. Cooper, C.L.; Davis, H.L.; Morris, M.L.; Efler, S.M.; Adhami, M.A.; Krieg, A.M.; Cameron, D.W.; Heathcote, J. CPG 7909, an immunostimulatory TLR9 agonist oligodeoxynucleotide, as adjuvant to Engerix-B HBV vaccine in healthy adults: A double-blind phase I/II study. J. Clin. Immunol. 2004, 24, 693-701.

43. Cooper, C.L.; Davis, H.L.; Angel, J.B.; Morris, M.L.; Elfer, S.M.; Seguin, I.; Krieg, A.M.; Cameron, D.W. CPG 7909 adjuvant improves hepatitis B virus vaccine seroprotection in antiretroviral-treated HIV-infected adults. AIDS 2005, 19, 1473-1479.

44. Gomis, S.; Babiuk, L.; Godson, D.L.; Allan, B.; Thrush, T.; Townsend, H.; Willson, P.; Waters, E.; Hecker, R.; Potter, A. Protection of chickens against Escherichia coli infections by DNA containing CpG motifs. Infect. Immun. 2003, 71, 857-863.

45. Gomis, S.; Babiuk, L.; Allan, B.; Willson, P.; Waters, E.; Ambrose, N.; Hecker, R.; Potter, A. Protection of neonatal chicks against a lethal challenge of Escherichia coli using DNA containing cytosine-phosphodiester-guanine motifs. Avian Dis. 2004, 48, 813-822.

46. Taghavi, A.; Allan, B.; Mutwiri, G.; Van Kessel, A.; Willson, P.; Babiuk, L.; Potter, A.; Gomis, S. Protection of neonatal broiler chicks against Salmonella Typhimurium septicemia by DNA containing CpG motifs. Avian Dis. 2008, 52, 398-406.

47. Mackinnon, K.M.; He, H.; Swaggerty, C.L.; McReynolds, J.L.; Genovese, K.J.; Duke, S.E.; Nerren, J.R.; Kogut, M.H. In ovo treatment with $\mathrm{CpG}$ oligodeoxynucleotides decreases colonization of Salmonella enteriditis in broiler chickens. Vet. Immunol. Immunopathol. 2009, 127, 371-375.

48. St Paul, M.; Mallick, A.I.; Read, L.R.; Villanueva, A.I.; Parvizi, P.; Abdul-Careem, M.F.; Nagy, E.; Sharif, S. Prophylactic treatment with Toll-like receptor ligands enhances host immunity to avian influenza virus in chickens. Vaccine 2012, 30, 4524-4531.

49. Barjesteh, N.; Behboudi, S.; Brisbin, J.T.; Villanueva, A.I.; Nagy, E.; Sharif, S. TLR ligands induce antiviral responses in chicken macrophages. PLOS ONE 2014, 9, e105713.

50. He, H.; Genovese, K.J.; Swaggerty, C.L.; Nisbet, D.J.; Kogut, M.H. In vivo priming heterophil innate immune functions and increasing resistance to Salmonella enteritidis infection in neonatal chickens by immune stimulatory $\mathrm{CpG}$ oligodeoxynucleotides. Vet. Immunol. Immunopathol. 2007, 117, 275-283.

51. Dar, A.; Potter, A.; Tikoo, S.; Gerdts, V.; Lai, K.; Babiuk, L.A.; Mutwiri, G. CpG oligodeoxynucleotides activate innate immune response that suppresses infectious bronchitis virus replication in chicken embryos. Avian Dis. 2009, 53, 261-267. 
52. Dar, A.; Tikoo, S.; Potter, A.; Babiuk, L.A.; Townsend, H.; Gerdts, V.; Mutwiri, G. CpG-ODNs induced changes in cytokine/chemokines genes expression associated with suppression of infectious bronchitis virus replication in chicken lungs. Vet. Immunol. Immunopathol. 2014, 160, 209-217.

53. Lee, J.Y.; Song, J.J.; Wooming, A.; Li, X.Y.; Zhou, H.J.; Bottje, W.G.; Kong, B.W. Transcriptional profiling of host gene expression in chicken embryo lung cells infected with laryngotracheitis virus. BMC Genomics 2010, 11, e445.

54. Purcell, D.A. Ultrastructural Changes Produced by Infectious Laryngotracheitis Virus in Tracheal Epithelium of Fowl. Res. Vet. Sci. 1971, 12, 455-458.

55. Keestra, A.M.; de Zoete, M.R.; Bouwman, L.I.; van Putten, J.P. Chicken TLR21 is an innate CpG DNA receptor distinct from mammalian TLR9. J. Immunol. 2010, 185, 460-467.

56. Chen, S.; Cheng, A.; Wang, M. Innate sensing of viruses by pattern recognition receptors in birds. Vet.Res. 2013, 44, 82-94.

57. Netea, M.G.; Simon, A.; van de Veerdonk, F.; Kullberg, B.J.; Van der Meer, J.W.; Joosten, L.A. IL-1 $\beta$ processing in host defense: Beyond the inflammasomes. PLoS Pathog. 2010, 6, e1000661.

58. Anders, H.J.; Banas, B.; Linde, Y.; Weller, L.; Cohen, C.D.; Kretzler, M.; Martin, S.; Vielhauer, V.; Schlondorff, D.; Grone, H.J. Bacterial CpG-DNA aggravates immune complex glomerulonephritis: Role of TLR9-mediated expression of chemokines and chemokine receptors. J. Am. Soc. Nephrol. 2003, 14, 317-326.

59. Mathes, A.L.; Rice, L.; Affandi, A.J.; DiMarzio, M.; Rifkin, I.R.; Stifano, G.; Christmann, R.B.; Lafyatis, R. CpGB DNA activates dermal macrophages and specifically recruits inflammatory monocytes into the skin. Exp. Dermatol. 2015, 24, 133-139.

60. Das, S.; Ghosh, A.K.; Singh, S.; Saha, B.; Ganguly, A.; Das, P. Unmethylated CpG motifs in the L. donovani DNA regulate TLR9-dependent delay of programmed cell death in macrophages. J. Leukoc. Biol. 2015, 97, 363-378.

61. Hashimoto, Y.; Moki, T.; Takizawa, T.; Shiratsuchi, A.; Nakanishi, Y. Evidence for phagocytosis of influenza virus-infected, apoptotic cells by neutrophils and macrophages in mice. J. Immunol. 2007, 178, 2448-2457.

62. Djeraba, A.; Bernardet, N.; Dambrine, G.; Quere, P. Nitric oxide inhibits Marek's disease virus replication but is not the single decisive factor in interferon-gamma-mediated viral inhibition. Virology 2000, 277, 58-65.

63. Haddadi, S.; Kim, D.S.; Jasmine, H.; van der Meer, F.; Czub, M.; Abdul-Careem, M.F. Induction of Toll-like receptor 4 signaling in avian macrophages inhibits infectious laryngotracheitis virus replication in a nitric oxide dependent way. Vet. Immunol. Immunopathol. 2013, 155, 270-275.

64. Schat, K.A.; Xing, Z. Specific and nonspecific immune responses to Marek's disease virus. Dev. Comp. Immunol. 2000, 24, 201-221.

65. Khatri, M.; Palmquist, J.M.; Cha, R.M.; Sharma, J.M. Infection and activation of bursal macrophages by virulent infectious bursal disease virus. Virus Res. 2005, 113, 44-50.

66. Ramos, H.J.; Lanteri, M.C.; Blahnik, G.; Negash, A.; Suthar, M.S.; Brassil, M.M.; Sodhi, K.; Treuting, P.M.; Busch, M.P.; Norris, P.J.; et al. IL-1beta signaling promotes CNS-intrinsic immune control of West Nile virus infection. PLoS Pathog. 2012, 8, e1003039. 
67. Cai, H.; Kuang, Z.; Huang, K.; Shi, J.; Zhao, X.; Chu, P.; Huang, C.; Ming, F.; Xia, F.; Yang, J.; et al. $\mathrm{CpG}$ oligodeoxynucleotide protect neonatal piglets from challenge with the enterotoxigenic E. coli. Vet. Immunol. Immunopathol. 2014, 161, 66-76.

68. Krieg, A.M. CpG motifs in bacterial DNA and their immune effects. Annu. Rev. Immunol. 2002, 20, 709-760.

69. Calnek, B.W.; Fahey, K.J.; Bagust, T.J. In vitro infection studies with infectious laryngotracheitis virus. Avian Dis. 1986, 30, 327-336.

70. Sharma, J.M.; Burmester, B.R. Resistance to Marek's disease at hatching in chickens vaccinated as embryos with the turkey herpesvirus. Avian Dis. 1982, 26, 134-149.

71. Wigley, P.; Hulme, S.D.; Bumstead, N.; Barrow, P.A. In vivo and in vitro studies of genetic resistance to systemic salmonellosis in the chicken encoded by the SAL1 locus. Microbes Infect. 2002, 4, 1111-1120.

72. Okamura, M.; Lillehoj, H.S.; Raybourne, R.B.; Babu, U.S.; Heckert, R.A. Cell-mediated immune responses to a killed Salmonella enteritidis vaccine: Lymphocyte proliferation, T-cell changes and interleukin-6 (IL-6), IL-1, IL-2, and IFN-gamma production. Comp. Immunol. Microbiol. Infect. Dis. 2004, 27, 255-272.

73. Haddadi, S.; Thapa, S.; Kameka, A.M.; Hui, J.; Czub, M.; Nagy, E.; Muench, G.; Abdul-Careem, M.F. Toll-like receptor 2 ligand, lipoteichoic acid is inhibitory against infectious laryngotracheitis virus infection in vitro and in vivo. Dev. Comp. Immunol. 2015, 48, 22-32.

74. Abdul-Careem, M.F.; Hunter, B.D.; Sarson, A.J.; Mayameei, A.; Zhou, H.; Sharif, S. Marek's disease virus-induced transient paralysis is associated with cytokine gene expression in the nervous system. Viral Immunol. 2006, 19, 167-176.

(C) 2015 by the authors; licensee MDPI, Basel, Switzerland. This article is an open access article distributed under the terms and conditions of the Creative Commons Attribution license (http://creativecommons.org/licenses/by/4.0/). 